\title{
THE ORGANIZED LABOR BUREAUCRACY AS A BASE OF SUPPORT FOR THE DEMOCRATIC PARTY
}

\author{
Nicholas A. Masters*
}

With the announcement of official top level labor support for the re-election of Franklin D. Roosevelt in 1936 , the Gomperian dictum of neutrality in politics received a mortal blow. Labor's neutrality, which had long been an equivocal tradition anyway, was laid to rest in 1955, with the merger of the politically aggressive Congress of Industrial Organizations (CIO) with the less politically oriented American Federation of Labor (AFL). These and other much-publicized events, such as organized labor's role in the I948 Truman victory and the 1958 congressional elections, have contributed to a widely-held popular belief that labor represents a monolithic force on the American political scene, capable of placing a massive vote at the doorstep of the Democratic Party. Yet recent scholarly studies demonstrate that, despite increasing political involvements of union leaders, particularly in campaigns, there are a substantial number of union members who vote contrary to the public endorsements of their leadership; who note with disapproval, as detracting from the vital business of contract and grievance negotiation, any display of political activity by union leaders; or who remain politically apathetic, leadership exhortation to the contrary notwithstanding. Moreover, within the union movement, a substantial number of union leaders still attempt to stay out of partisan election campaigns, and refuse to allow their unions to become closely identified with any political party or its candidates.

The intention of this paper is to discuss, first, the generalization that union organizations and their members occupy varying positions on a continuum of political opinion and activity, and that as a result the AFL-CIO cannot guarantee a substantial bloc of votes for candidates in national campaigns. In the light of previous studies, this point does not merit detailed documentation and analysis. And second, the major focus of this discussion is on an analysis of organized labor, particularly the AFL-CIO nationally, as a base of support for Democratic candidates for presidential and congressional offices. Such analysis involves two questions: Why is labor sought as a base of support? What are the effects, positive and negative, of such support?

DIVERstTy in Labor Support

While union leaders have over the years fought for the right to strike, to organize, to bargain with employers, and to engage in the collective promotion of their eco-

- Ph.D. 1955, University of Wisconsin. Visiting Associate Professor, 1961-62, Washington University, St. Louis, Mo. Associate Director of a research project sponsored by the Carnegie Foundation entitled "State Politics and the Public Schools." Contributor to political science periodicals. 
nomic and social welfare by means of the ballot-box and lobbying, they seldom agree on candidates, parties, or issues. It is not a novel proposition to point out that "the American labor movement is a highly complex social phenomenon with myriads of dissimilar features at lower levels. These diversities are multiplied in the alliances and organizational arrangements improvised for political purposes within organized labor and between organized labor and other political groups."1 For example, the bulk of the political activity carried on by the AFL-CIO in national campaigns is supported extensively by only a few unions, namely, the United Automobile Workers of America (UAW), the United Steelworkers of America (USW), the International Ladies Garment Workers Union (ILGWU), and the International Association of Machinists (IAM). And even within this group, there are some variations. The UAW in Michigan is openly partisan and for all intents and purposes is an integral part of the Democratic Party in that state. In New York State the ILGWU'S political arm is the Liberal Party, which occasionally nominates its own candidates, but usually gives its support to the Democrats. ${ }^{2}$ A more moderate approach is taken by the USW which, under President David MacDonald's leadership, has stopped short of open affiliation with the Democratic Party and extensive participation within the Party's internal framework.

Furthermore, a substantial part of the union movement has been conservatively oriented politically. Conservativism among unions might be defined in the following manner: (I) apathy toward or avoidance of national election activity; (2) an overwhelming concern with the political and economic problems of their own union, with little or no interest in the problems of other unions or other segments of society; (3) tight control from the top, with few avenues open for membership participation in policy decisions. Dominated by the late William Hutcheson, a Republican, the United Brotherhood of Carpenters and Joiners of America has a reputation for headquarters control and political conservatism and disinterest. Building and other skilled trade unions have manifestly turned their energies toward control of jobs rather than concern with political issues, and have avoided direct participation in election campaigns. This is not to suggest that conservative unions are politically apathetic and never press for legislation or participate in the determination of state and local governmental decisions. On the whole, however, this type of union deliberately and carefully avoids partisan commitments. In brief, organized labor is not unified politically and it is very unlikely that it will be in the foreseeable future. Strictly speaking, organized labor is not, in terms of its organization and leadership, a unified base of support for any candidate or party.

The growing body of union vote analysis supports the point made earlier that the union membership, while characteristically voting for Democratic candidates, is by no means in the pocket of its leadership or the Democratic Party. In the 1956 presidential election, for example, the Survey Research Center found, by dividing

${ }^{2}$ Alexander Heard, The Costs of Democracy i76 (Ig60).

'Seidler, The Socialist Party and American Unionism, 5 Mrowest J. Por. ScI. 207, 228 (196r). 
their sample of union members according to their one-time AFL or CIO affiliation, that AFL respondents voted fifty-one per cent Democratic, whereas sixty per cent of the CIO members favored the Democrats. ${ }^{3}$ E. E. Schattschneider, in his most recent work, points out that although the AFL-CIO membership totals $16,000,000$, generous estimates put its normal voter-turnout at about half this figure. The Republican Party's share is estimated at $2,400,000$ of the $8,000,000$ votes cast, leaving the Democrats with approximately 5,600,000.4 In brief, the total Democratic vote supplied by organized labor may be only about one-third of the total membership figure. Supporting the implication of Schattschneider's rough calculations are the findings from surveys ordered by George Meany, following the $195^{2}$ and $195^{6}$ presidential elections. The surveys of union voting conducted in Illinois and New Jersey revealed that the turnout of eligible voters among unionists was below the national average of non-union voters. The AFL-CIO president was, thus, induced to call for a vigorous union-sponsored get-out-the-vote drive for 1960 . Another conclusion coming out of the Meany surveys was that while union men had, on the whole, supported Stevenson, their wives had voted for Eisenhower.

Some unions' members, however, are much more solid in terms of voting behavior; and because they back their leadership, these unions become significant bases of support for candidates running for national or congressional offices in the areas of their membership concentration. The UAW membership in Michigan, for example, strongly supports the Democratic Party, although its membership elsewhere has not been recognized as a unified, potent political force. Kornhauser, Sheppard, and Mayer, and later Sheppard and Masters, found that a majority of union members in the Detroit area consistently support Democratic candidates in state and national elections, and generally approve of and support the UAW's extensive political commitments. Nevertheless, both studies demonstrated that fifteen to twenty per cent of the membership are opposed to the union's political policies and about twenty-five per cent are either apathetic or uncommitted though normally inclined to vote Democratic. ${ }^{5}$

With such disunity in labor's ranks, why all the fuss about labor endorsements? The data supplied by scholarly studies and academic discussions seem to imply that there is little operative political necessity for any elaborate efforts to gain organized labor support except in those areas, such as Detroit, where unionists constitute the bulk of the population and are mobilized through union political organizations. A prevalent belief amorig some political scientists is that failure to gain organized labor support is not a major disadvantage to a Democratic candidate in the majority of cases, and that the immediate political power of labor at the polls is fairly limited. Unfortunately, the political role of the labor bureaucracy in presidential and

s Angus Campbeli et al., The American Voter 3 I2 (1960).

E. E. Schattscenneider, The Semi-Sovereign People 50 (1960).

- Arthur Kornhauser, Harold L. Sheppard \& Albert J. Mayer, When Labor Votes: A Study of Auro Workers (1956); Sheppard \& Masters, The Political Attitudes and Preferences of Union Members: The Case of the Detroit Auto Workers, 53 AM. PoL. Scr. Rev. 437 (1959). 
congressional elections has not been properly appraised. Although a great deal has been learned about the political variations within the labor movement and the voting behavior of unionists from recent studies, we have neglected to examine why organized labor is sought and what its effects are as a base of support for the Democratic Party in national campaigns. The remainder of this paper is devoted to such an examination.

\section{II}

\section{Advantages of Labor Support}

\section{A. Votes}

The closeness of the 1960 presidential election has again brought home the point to politicians that any strategem that will affect even the slightest sprinkling of votes may be extremely critical to the final result. The same election also showed the tremendous influence of the large urban areas on electoral vote majorities. In view of the concentration of the most politically active and vigorous unions' membershipunions which support the Democratic Party-in the large urban areas within states having the largest electoral votes, AFL-CIO support has come to be regarded as essential for the effect it may have on perhaps only a small portion of the total union membership in these areas. That is, endorsement and active leadership support may persuade a few more unionists and members of their families to vote for endorsed candidates, or simply to vote. Although political scientists have not yet developed precise methods for measuring the effect of open support and related activity, Campbell et al. have hypothesized that when individual members of a group begin to get a clearer perception of the proximity of the group and the world of politics-and presumably aggressive political action programs are more likely to generate clearer perceptions-the susceptibility to group influence in political affairs increases. ${ }^{8}$ True, politicians may not use these terms or they may not be able to articulate the point at all, but most of them are aware of the fact that the elaborate political activities of unions have had an impact on the voting decisions of some members. Consequently, candidates for the Presidency and for Congress in areas of labor concentration want identification with, and the support of, both unions in the area and the AFL-CIO nationally. Support is desired not because union political actionists control a large bloc of votes that they can swing one way or another-they have never had this kind of control-but rather because they may be able to affect the size of the urban majorities for the Democratic Party. This fact alone, despite the political variations within the labor movement, gives the AFL-CIO nationally a much greater voice in the Democratic Party and governmental affairs.

In politics, power relationships are determined and affected by the resources at the disposal of the participants. An important element of power is control over votes. The bureaucracy of organized labor realizes that this resource, this element

- Campeell et al., op. cit. supra note 3, at 3 II. 
of its power, is not an entirely flexible one, that it can be used only in a restricted manner. Labor's political strength lies in cities like Detroit, Chicago, Pittsburgh, New York, Los Angeles, and St. Louis, that produce the large majorities for the Democrats in presidential and state-wide election contests. This means that the AFL-CIO must remain Democratic in order to maintain a strong and viable bargaining position in politics. It is extremely doubtful that the AFL-CIO could directly influence the size of the Republican minorities in these areas, and the idea that an independent third party can be formed in the event of dissatisfaction with the Democrats is ridiculous. The present structure of the labor constituency is a relatively recent development which, in part, may account for organized labor's earlier caution in political affairs and its refusal to identify with either party. In the local arena or in some cities elements of organized labor have long had a strong voice and have participated in elections, but labor's influence nationally did not come until it had the resources of power, namely, votes and money. In the past, particularly before the emergence of the large industrial unions, union membership was not concentrated in the cities, and the cities were not as Democratic as they are today. The United Mine Workers Union (UMW) twenty years ago, for example, despite considerable political activity, had little influence on national elections, primarily because its members were not so strategically located as are the members of the industrial unions today. It should be noted also that the conservative unions are the ones whose memberships are sprinkled throughout the nation rather than concentrated in key political areas. Thus, in a desire to attain more influence in government, the AFL-CIO has adopted the political positions of its industrial-CIO type unions rather than those followed by the older craft-AFL type. AFL-CIO leaders have turned to national election activity in addition to lobbying because they know their economic power can be severely curtailed by political actions (Taft-Hartley, Landrum-Griffin, etc.). Bart Cochran puts it this way: " ". . fifteen years of pressure politics have failed to alter the contour of American politics. What is even worse they have been insufficient for labor to hold its own." Labor's influence over votes presumably prevents incumbents from using their power indiscriminately against labor, or guarantees that incumbents will be favorably disposed toward labor's goals. This being the source of its political bargaining power, the AFL-CIO's alliance with the Democratic Party is firm, although not always openly espoused.

In addition to the influence labor leaders may have on the size of urban majorities, organized labor has gained representation at Democratic national conventions. Approximately one-eighth of the delegates to the 1960 Democratic National Convention were unionists. It comes as no surprise that the majority of the union delegates were from the big industrial states, although there were a few from southern and western states. Organized labor, obviously, did not control the convention, but its delegates, coupled with the votes of delegates not directly

\footnotetext{
${ }^{7}$ Cochran, Ametican Labor in Midpassage, in Bart Cochran (Ed.), American Lador in Midpassage I, 42 (I959).
} 
involved in the labor movement but committed to its objectives, gave labor a strong voice in the choice of candidates, and an even stronger voice in the formulation of platform provisions. The following data illustrate the delegate strength of unions from some of the large industrial states:

$$
\begin{aligned}
& \text { Michigan-I02 delegates, } 50 \text { alternates; } 34 \text { union officials } \\
& \text { and } \eta \text { industrial workers. } \\
& \text { Minnesota-62 delegates; ro union. } \\
& \text { California-I62 delegates; } 16 \text { union. }
\end{aligned}
$$

On the Republican side, only ten delegates to the Party's national convention were unionists.

\section{B. Money}

Organized labor has been able to extend its influence outside the areas of labor concentration by offering candidates who are pro-labor a scarce and essential commodity-namely, money. Alexander Heard points out that: ${ }^{8}$

... the two million dollars or so of free funds that $I 7$ million union members gave in I956 about equalled the reported voluntary contributions of $\$ 500$ and over made by 742 officials of the nation's 225 largest business concerns.

(The two-million figure is equal to approximately only three-tenths of one per cent of annual union dues.) Candidates for Congress in predominantly rural and nonindustrial areas, e.g., Montana and Idaho, where labor identification does not mean the kiss of death, but where local labor unions are not large enough to be affluent, seek labor endorsements "from the East" in order to obtain AFL-CIO money. In such instances, both labor and the candidate may have to play down labor support somewhat because the popular image of organized labor is not entirely favorable, and some of the members of a candidate's own party may resent "outside" influence. Of course, the source of money in campaigns is seldom kept quiet, at least for very long, and opposing candidates have not hesitated to use the labor domination theme. The influx of labor money has resulted in situations today where conservative forces are using a traditionally liberal symbol. Conservatives, rather than liberals, since they are now able to finance their own political activities almost entirely out of local and state sources, are the ones who charge the opposition with "domination of the monied interests from the East."

How extensively national labor money is brought into the various states during a campaign can be noted from data on the $195^{6}$ presidential election. In that year, national labor money "went to back Democratic senatorial candidates in 22 of the 33 states from which senators were elected, the remaining II consisting of seven Southern and two Northern one-party states plus Arizona and Kansas." In the same election "one or more Democratic candidates for the House of Representatives received national labor gifts in every state but six, all of the latter being one-party states, except New Mexico."9

\footnotetext{
${ }^{8}$ HeArd, op. cit. supra note $\mathrm{I}$, at 196.

Id. at $\times 87$
} 
That contributions from national labor are more crucial than efforts of local unions in the financing of certain campaigns can be inferred from the fact that in I956 of $\$ 1,024,258$ total labor donations to candidates for federal office or to their campaign committees, $\$ 831,700$ came from seventeen national labor groups, with only $\$ 192,558$ coming from 155 state and local labor groups.

Heard breaks the figures down further in tabular form, showing that of the money coming from national labor organizations, by far the largest single amounts were spent on behalf of specific candidates for the House and Senate-amounts of $\$ 335$, I55 and $\$ 326,045$ respectively. In addition, \$109,000 was donated to political committees on the national level and $\$ 61,500$ was given to political committees on the local level. The bulk of the money from local and state labor groups $(\$ \times 38,893)$ was spent to aid specific candidates for the House of Representatives. Of the remainder of local labor money, $\$ 42,863$ was spent to aid specific senatorial candidates, $\$ 7,678$ went to local political committees, and $\$ 3$, I24 was donated to national political committees. ${ }^{\text {.0 }}$

Except for $\$ 3,925$, which was split among eight Republican candidates for the House of Representatives, all labor money went to Democratic candidates. And, for the years $195^{2}$ and $195^{6}$ about "one-seventh of the direct expenses of national-level pro-Democratic committees were met with labor money."11

\section{Organization}

Party professionals seemingly complain more about the lack of party organization and money than anything else. The AFL-CIO has been able to provide for the Democratic Party one thing business interests have been unable to supply for the Republicans-namely, organization. The most fundamental point to emphasize is the sheer muscle union workers can provide in a campaign. It is easy to say organized labor provides workers, but it takes almost direct involvement to appreciate what this means. "Getting out the vote" involves climbing stairs, driving through heavy traffic, listening to crying babies, pounding the pavements from one block to the next, and performing a multitude of unglamorous tasks which most middleclass suburbanite Democrats or ADA-type Liberals will not perform or are physically unable to perform. In the Ig6o election, the AFLrCIO launched the biggest effort in its history. An account of some of the steps it took in this election serves to illustrate what organized labor offers as a base of support for the Democratic Party.

\section{Registration Drives}

Based on the carefully documented assumption that more people are Democrats than Republicans, the Committee on Political Education (COPE), the political arm of the AFL-CIO, assisted by a special committee set up to handle fourteen key states, embarked on an all-out registration drive in each of the fifty states early in 1960 . The effort, financed from donations from each AFL-CIO union at the rate of five

${ }^{10} \mathrm{Id}$. at $\mathrm{I} 86$.

${ }^{21}$ Id. at 188 n. 45. 
cents per member, with any deficits to be made up from the general treasury, yielded impressive results. In St. Louis, 407 unionists registered 85,077 new voters in one day. In Allegheny County (Pittsburgh), Pennsylvania, 43,490 new Democrats were registered as compared with 29,724 new Republicans. In cooperation with other groups, labor registered 100,000 new voters in Spanish-speaking sections of California. In addition to manpower, COPE furnished money to help pay for office rent, radio and TV spot announcements, gasoline, baby-sitting, loudspeakers, floats in parades, and other items.

\section{Distribution of Literature}

COPE published and paid for ten million leaflets on the voting records of congressmen which reported their "right" and "wrong" positions according to AFL-CIO standards with respect to ten issues. In addition, five million leaflets were distributed that revealed Senator Kennedy voting "right" 9r.6 per cent of the time as compared with Vice-President Nixon's 76.6 per cent "wrong" voting record on key labor issues.

\section{Get Out the Vote}

Employing a variety of tactics ranging from transportation to baby-sitting for voting mothers, large crews of union workers, some of them paid from union funds, attempted to get unionists and members of their families to the polls. COPE, for example, in Senator Kefauver's successful battle for Tennessee's Democratic senatorial nomination, made 60,000 telephone calls, mailed 300,000 copies of Kefauver's campaign literature, distributed 160,000 leaflets, and set up a central file containing the names and addresses of 65,000 unionists in the state.

Beyond its organizational efforts in an election year, the AFL-CIO, along with a number of its international unions, conducts political education programs, informs members about the voting records of incumbents, registers voters, and so on.

\section{The Liberal Sanction}

Endorsement and support from organized labor, or some segments thereof, frequently help a candidate to rally support from other self-designated liberal groups. Organizations, such as the Americans for Democratic Action, the National Association for the Advancement of Colored People, the American Civil Liberties Union, and their thousands of local chapters or units, usually will not back a candidate whose acceptability to organized labor is highly questionable. Moreover, the National Committee for an Effective Congress seldom supports a candidate with an antilabor background.

The importance of the liberal sanction is illustrated by the pre-convention struggle among the Democrats prior to the I 960 election. The discussion that follows, however, rests primarily on newspaper accounts, which, although perhaps generally reliable, certainly do not provide a detailed account of exactly what happened. 
Preliminary discussions of the desirability of union neutrality in the 1960 presidential election ended with the realization that in the impending presidential contest, labor neutrality would increase the chances of a Republican President. In fact, it was soon realized by some union leaders that even though no formal action could be taken nationally before the Democratic nomination, organized labor had to get into the pre-convention fight to insure the nomination of a liberal candidate. Early in that year, Democrats Kennedy, Symington, and Humphrey were busy lining up labor endorsements not only because labor could affect votes both at the convention and in the election, but also because labor support helped to pave the avenues toward other liberal endorsements and acceptability. But failure to attract organized labor as a base of support significantly damaged Lyndon Johnson's bid for the Democratic presidential nomination.

For a number of reasons, Johnson was almost totally unacceptable to organized labor, and even after he received the vice-presidential nomination many labor leaders remained decidedly cool. Unacceptability to organized labor made it difficult for Johnson to gain support from other liberal groups, and without it he was virtually cut off from the large body of delegates representing the Northeastern industrialized areas. Party professionals in these areas, who perhaps may have been sympathetic toward Johnson, simply would not risk the alienation of organized labor. Moreover, leaders within the union bureaucracy who might have felt that Johnson had done a tremendous job as majority leader in the Senate during the Eisenhower years still found it impossible to support him. To support Johnson would require a change of policies; "it would make us seem inconsistent," one AFL lobbyist said. The extent of organized labor's opposition to Johnson was aptly expressed by The Economist: ${ }^{12}$ "It is doubtful whether the unions could swallow the gnat of Senator Johnson's nomination, even if this refusal subsequently obliged them to digest the camel of Mr. Nixon's Presidency." Johnson was distrusted by labor primarily because he was trusted by Southern Democrats. It was felt, particularly by the UAW in Michigan, that Johnson, despite his New Deal background, had too many commitments to southern legislators and the oil interests of his native state of Texas to use the power of the Presidency to protect and promote the interests of labor. There is little doubt that labor support might have gained Johnson the nomination. Support is a significant input factor in campaigns which functions so that the acts and statements of the endorsee will be accepted and understood by the public. Such support serves to prevent distrust or lack of confidence in the candidate by those sympathetic to or appreciative of a group's views, and who judge a candidate as to whether he can speak authoritatively in approval of programs advocated by a particular group. Johnson, despite his record, could not speak authoritatively in support of labor goals before liberal groups committed to labor's programs.

It is not intended to imply, however, that organized labor support guarantees that other groups will be similarly inclined. A candidate for the presidential nomi-

2s The Economist, April 9, 1960, p. I5I. 
nation with labor support simply has a better chance than others. And, of course, labor itself is strongly influenced by the acceptability of a candidate to other groups, liberal and conservative alike. In the 1960 pre-convention period, for example, the sentimental favorite of organized labor was Senator Hubert Humphrey. But Humphrey could not convince labor and other liberal groups that he was a winner, and principles alone were not a sufficient ground for support. A long, hard look at the results of the Wisconsin and West Virginia primaries indicated to labor leaders that support for Humphrey would be futile. Today, labor recognizes that its support inevitably involves burdens and obligations that may cause other segments of society to react adversely, or with total disapproval. Thus, an effort is made to generalize its support, endorsing candidates who have broad, across the board approval, and recognizing that they must appeal to other groups. Labor leaders felt that the Humphrey appeal in an election would be confined to what may be loosely termed the organized labor-northern liberal bloc, a combination not powerful enough to capture the nation.

A Symington candidacy, on the other hand, was considered by many labor leaders to be desirable because he had avoided being labeled an extremist, and his background made him acceptable to management groups. Symington's efforts certainly did not ignore labor. Early in the pre-convention campaign, Symington received the endorsements of James Carey, President of the International Union of Electrical, Radio and Machine Workers, and George M. Harrison, President of the Brotherhood of Railway Clerks. Unquestionably these endorsements made Symington's bid for the nomination more acceptable to other liberal groups, as indicated by labor's desire later for him to receive the vice-presidential nomination; but they did not result in widespread support. "Models for industry" was the slogan attached by Carey and Harrison to contracts negotiated by Symington while president of Emerson Electric.

But the Kennedy bandwagon rolled on, not to be upset by a few endorsements for other candidates from within the labor movement. In fact, significant forces within organized labor, not only assessing the potentialities of those who might be acceptable to labor ideologically, but also looking for a sure winner, attached themselves to Kennedy, even though his equivocal stand on McCarthyism and his failure to fight for civil rights legislation dampened their enthusiasm. The UAW, USW, and the Textile Workers Union of America endorsed Kennedy early, and devoted their pre-convention efforts to insuring his nomination.

In Michigan, strong UAW backing was instrumental in convincing party professionals and leaders of liberal groups that Kennedy should receive the state's delegate votes at the convention. Leaders of Negro groups, in particular, who were at first very cool toward Kennedy, were persuaded by union officials to support his candidacy. In effect, these unions and other groups were playing the percentages, fearful of being left out should the Kennedy forces win. With this much preconvention support, particularly from two of the largest and most politically active 
unions within AFL-CIO, it was a foregone conclusion that AFL-CIO would give its endorsement in the post-convention meeting of its general board. A few unions still refused to go along (the United Brotherhood of Carpenters and Joiners, the International Association of Machinists, and, of course, the International Brotherhood of Teamsters, who are outside the AFL-CIO organization); but the base of support was there.

\section{E. Propaganda Advantage}

A significant part of the success of any candidate is to gain and hold the attention of the attentive public, to make sure that informed people are aware of his candidacy and his position on the various issues in the campaign. The difficulty involved in becoming known is not commonly appreciated. Money is a crucial variable and labor supplies some of the funds necessary for purchasing TV time, radio programs or announcements, and newspaper advertisements. Articles about candidates and their backgrounds in labor publications-and there are hundreds of them-which reach and are read by intermediate level union leaders help to provide a flow of information to the rank and file membership. ${ }^{13}$ Invitations to candidates to speak before union meetings, furnishing them with captive audiences, also contribute to the significance of labor as a base of support for candidates for public office. Perhaps of greatest significance, however, is that a candidate can cut into the network of interrelationships among community elites through labor leaders. AFL-CIO leaders, through overlapping memberships, help to do this for presidential candidates. Labor leaders within particular internationals, or who are part of the state and local AFL-CIO bureaucracy, help candidates for other offices. Today labor leaders participate extensively in a variety of civic, fraternal, and political groups in their communities, and they are included in all types of academic, governmental, and business conferences where they interact with the leaders of other groups. ${ }^{14}$

One of the most significant aspects of labor's new status is the silent revolution which has taken place during the last decade [1940-1950] with respect to union participation in local community services. ... On the Community Chest staffs of most of the cities there are now one or more union persons employed fulltime, acting as liaison between the social agencies and the unions helping on the fund-raising committees and the planning of the programs. Throughout the country there are thousands of union members serving on the local boards of the various agencies. ... Union participation in these local activities is put into effect through the AFL Central Labor organizations and the CIO Industrial Union Councils, and has become one of the major functions of these central federations.

Labor leaders, acting in these arenas where their opinions are respected, can and do advocate candidates for office.

13 "The various labor organizations are regularly publishing some 600 papers and journals. . . [I]t can be assumed that one or more labor papers are now being received regularly in almost 15 of the 43 million households throughout the country." Florence Petersen, AMerican Labor Unions I25 (x952).

14 Id. at 132-33. 


\section{LimitatToNs OF LABOR SUPPORT}

\section{A. "Excessive" Liberalism}

In assessing labor as a base of support it is necessary to look into its limitations. The political education programs initiated and conducted by the various political arms of the labor movement have borne fruit, but the fruit is often unsophisticated and the efforts have frequently promoted a rigid, closed-minded adherence to pat liberal solutions for complex issues. Almost necessarily the programs have stressed slogans and been superficial; and the propaganda has insisted on what many regard as an uncompromising liberal, pro-labor commitment. This commitment has frequently made it difficult for Democratic candidates to maintain full labor support and at the same time adjust their positions to what they think or believe are existing political realities. Intermediate and lower-level union leaders have in a great many cases shown a reluctance to support, or have refused to support vigorously, candidates who do not buy in toto the "Labor" position on economic and social issues. In the eyes of some veteran observers, "the screaming liberal line" found in the political education programs has made it difficult for labor's top echelon, whenever they desire to take a more practical position, to sell their members on candidates who do not meet all the issues head-on. Moreover, the tough ideological line in some instances has even forced the leadership to narrow its perspective in order to keep faith with the local and intermediate level of the union bureaucracy. ${ }^{15}$

Rigid adherence to the anachronisms of the New Deal ideology has often left significant elements within the labor bureaucracy with no place to go in campaigns and has, in some cases, severely handicapped its efforts to promote the passage of legislation it favors. On the whole, labor, especially the national headquarters of the AFL-CIO, is moving away from dogmatism and is attempting to offer more generalized support, but seemingly at a less accelerated pace than some other liberal groups. Kennedy's candidacy, for example, raised serious doubts in the eyes of those union leaders who supported him most strongly, specifically because of his record on the two issues mentioned previously, and more generally because he demonstrated few ideological commitments.

\section{B. Decline of the Industrial Unions?}

Labor leaders have begun to express grave concern about the future. For some time they have been talking about the threats of technological unemployment both to the union movement and the national economy. In a few states unions have proposed the creation of some kind of state commission to control the effects of automation. Today, technological unemployment is no longer merely a threat to union; it is a reality with which they must cope. Membership has begun to drop off

${ }^{16}$ The material presented here is based on close observation of and participation in labor's political activities in both Detroit and, to a lesser extent, St. Louis. Also the points are based on numerous discussions with AFL-CIO lobbyists in Washington. 
significantly in some unions, especially the UAW and USW. For the first time, union leaders are accepting the idea that they do not have a self-perpetuating future. Until very recently, labor leaders, somewhat like our early pioneers who thought there were endless forests, looked at all the unorganized workers and felt that they could always maintain their relative power in society through periodic expansion.

But now they can see that before very long their political and economic power will begin to decline unless something happens to alter the picture. Most labor officials are of the opinion that their power is at its apogee at present and is about to turn down. Some years earlier, I953, to be exact, Daniel Bell, writing for Fortune magazine, pointed out that "organized labor has probably passed its peak point" politically and economically. ${ }^{16}$ The lifting of the 1959 -1960 recession without substantial change in unemployment figures shows the speed with which the new automation and technological revolution is progressing. Although the writer cannot document this, there seem to be fewer jobs today than five years ago that are potentially unionizable. One thing is fairly certain, however, and that is that the conflicts among the craft and industrial unions have slowed the merger's fundamental drive to organize unattached workers, and the unions now have a smaller proportionate share of the national work forces than ten years ago. ${ }^{17}$

What does this mean politically? In the first place, the big industrial unions have been hit the hardest by automation. And, as mentioned earlier, these are the unions that are the most active politically, that contribute most of the money and organization in national campaigns, and that have their membership most strategically located in terms of affecting the outcome of presidential elections. If the resources and membership of these unions begin to dwindle, the significance of labor as a base of support for the Democratic Party will dwindle. It is, of course, plausible that union leaders will turn more to pressure group politics and away from party and campaign politics nationally to delay uncontrolled change and to compensate for the economic power slipping from their grasps. Walter Reuther's increasing concern about the outcome of decisions affecting agriculture is, in part, explained by a desire to forge stronger alliances with other economic groups, in this case the Farmers Union, to offset labor's declining political power. But the road ahead for the AFL-CIO looks rough; it may have fewer votes to play with, less money, and a weaker organization. It is little wonder then that the AFL-CIO is giving serious consideration to re-admitting the Teamsters Union, despite the national image the union has, and the antipathy many labor leaders have toward Teamster President James Hoffa.

\section{The Popular Image}

It is not difficult to substantiate the point that organized labor still conveys a poor image. The publicity engendered largely by investigations conducted by Senator

${ }^{10}$ Bell, The Next American Labor Movement, Fortune, April I953, pp. 120, 204.

${ }^{17}$ Krock, Three Houses Divided Against Themselves, N.Y. Times, July 7, 1960, p. 30, col. 4. 
McClellan's Committee has hurt American trade unions to a point where the AFL-CIO has felt the need to institute a $\$ 1.2$ million public relations programs. ${ }^{18}$ Such adverse publicity has served to confirm in the minds of many the negative stereotype they have of trade unions in general and union leadership in particular.

The image labor conveys, of course, limits and affects its political role. As previously mentioned, in some areas labor endorsement carries the kiss of death, and even in Michigan, where organized labor is recognized and accepted as an integral part of the Democratic Party, elaborate efforts are made by party professionals to make certain that the public does not think the Party is dominated and controlled by the UAW. More widespread participation by labor leaders in community affairs has helped to change the image, but many people in rural and non-industrialized areas still view unions with suspicion and massive distrust and refuse to support candidates prominently identified with them.

${ }^{18}$ Pomper, The Public Relations of Organized Labor, 23 PuB. OpINIoN Q. 483 (1959). 